\title{
Comparative Analysis of Facade Work Using Kumkang Precast, Concrete Precast, and Curtain Wall Methods in terms of Cost and Time
}

\author{
Irriene Indah Susanti and Maria Siwi Tiarasari \\ Civil Engineering Department,Mercu Buana University, Jakarta, Indonesia \\ irriene.shanty@gmail.com, mariasiwits97@gmail.com
}

\begin{abstract}
The development of the construction world in terms of innovation has become one of the methods of supporting success to gain advantages in terms of cost and time, one of which is the outer wall which can generally categorize into cast-in-situ and precast methods. (1) Comparison of the cost of implementing precast kumkang materials, precast concrete facades, and curtain wall facades. The precast kumkang method is $24 \%$ cheaper than the precast concrete method, the precast kumkang method is $87 \%$ cheaper than the curtain wall method, and the precast concrete method is $52 \%$ cheaper than the curtain wall method. Sorted from the cheapest to the most expensive are precast kumkang facades, precast concrete facades, and curtain wall facades.(2) Comparison of the working time of precast kumkang materials, precast concrete facades, and curtain wall facades with the results, namely curtain wall facades for 31 weeks, kumkang material precast facades for 53 weeks, and precast concrete facades for 55 weeks. Sorted from the fastest to longest, namely curtain wall facades, precast kumkang material facades, and then precast concrete facades.
\end{abstract}

\section{Keywords:}

Construction Cost Analysis, Construction Time Analysis, Curtain Wall Facade Work, Kumkang Material Precast Facade Work, Precast Concrete Facade Work.

\section{Introduction}

\subsection{Background}

In construction work, the material was select by considering several aspects such as the required cost aspect, the processing time aspect, and the material management aspect to maximize a job Hidayat \& Irvan, (2018). The building facade is the main face or front view of a building exterior that can see from the road or other public areas Soenarto et al., (2017). The big difference between the facade with the kumkang precast method, precast concrete, and curtain wall was using the formwork materials.

Aluminum panels are pre-design according to architectural plans to appear from the finished building with concrete. Forms into a single unit of columns, beams, stairs, shutters, facades, arched sections, and other intricate decorative features AYOMA Apartment, (2018). While the reference for object research for the precast concrete and curtain wall base on the Indonesian regulatory standards PermenPUPR and SNI. The precast concrete facade used standard formwork made of phenol film with casting carried out at the precast concrete factory. And for the curtain wall facade does not use formwork but melting glass raw materials into becoming glass tempered as a building wall covering panel.

\subsection{Problem Identification}

Based on the background, the researcher identified the existing problem as follows:

1. There is no comparison of facades between; the precast method of kumkang material to standard method concrete, or glass in terms of cost and time.

2. The development of the construction world today is required to pay attention to the aesthetics of the outside appearance.

\subsection{Problem Formulation}

Based on the background and problem identification, the researcher formulated the problem as follows:

1. What is the ratio of the costs required for the facade work on the kumkang material precast method, precast concrete, and curtain wall?

2. What is the ratio of the time required for facade work on the kumkang material precast method, precast concrete, and curtain wall? 


\section{Methods}

\subsection{Research Concept}

This research is a study to determine the requirements of each facade work between the precast method of kumkang, concrete, and curtain wall materials in terms of cost and construction time.

Figure 1. Kumkang Material Precast Facade

Figure 1 shows that most of the stages of the precast kumkang material are different from the others.

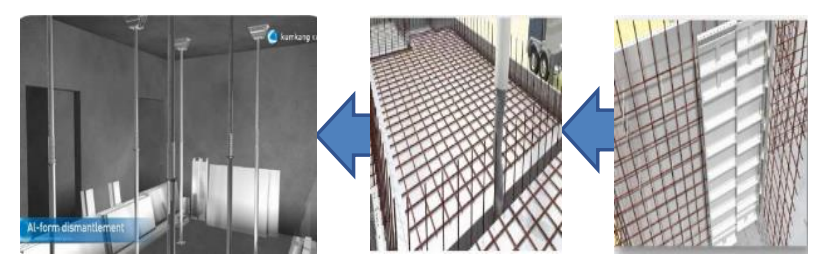

Figure 2. Precast Concrete Facade

Figure 2 shows most of the precast concrete facade stages.
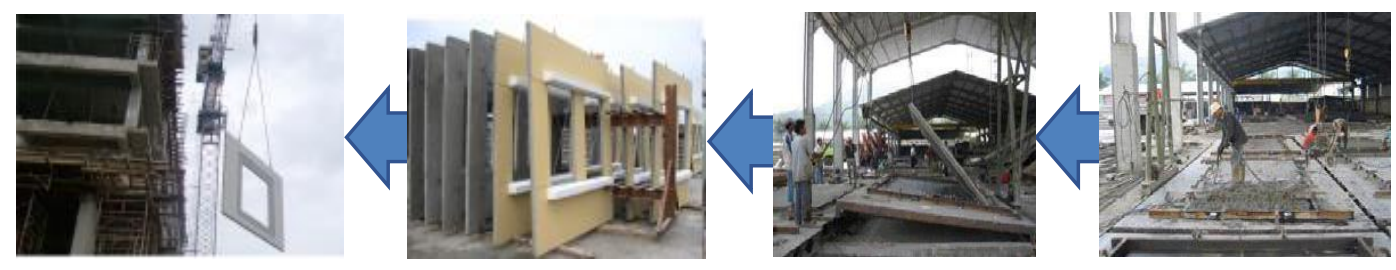

Figure 3. Curtain Wall Facade

Figure 3 shows most of the different stages of the curtain wall facade from the others.
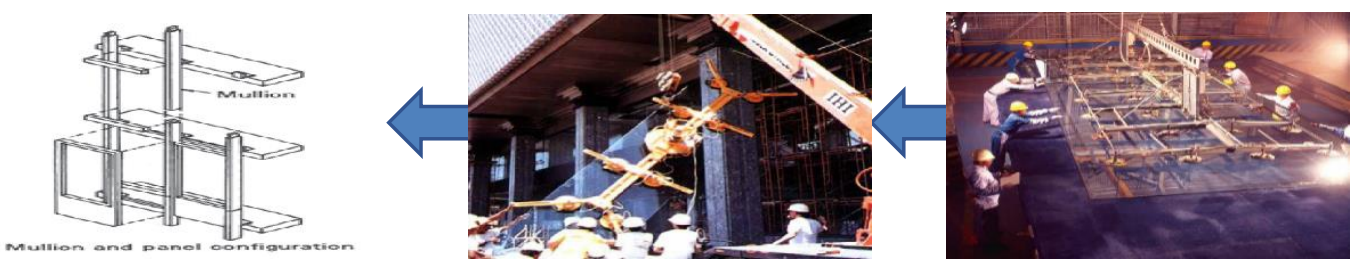

\subsection{Research Methods}

The research method in this study is comparative research with data in the form of numbers. The data obtained from the Mahata Margonda Apartment Project are BoQ, S curve, construction drawings, supporting data, AHSP PermenPUPR and SNI, and others. (1) The cost data is analyzed in AHSP format with RAB results for each method. (2) Time data is analyzed in terms of requirements per job with bar chart results from each method.

\section{Result and Discussion}

\subsection{Result}

(1) The cost analysis uses a two-part calculation. The first one is Unit Price Analysis/AHSP, which is the multiplication of material, labor, and equipment needs with unit prices according to each work according to the project area to complete the work unit. The second calculation is the volume of work needs, the multiplication of the two parts is explained in the Budget Plan/RAB, as shown in the table below: 
Table 1. RAB Comparison

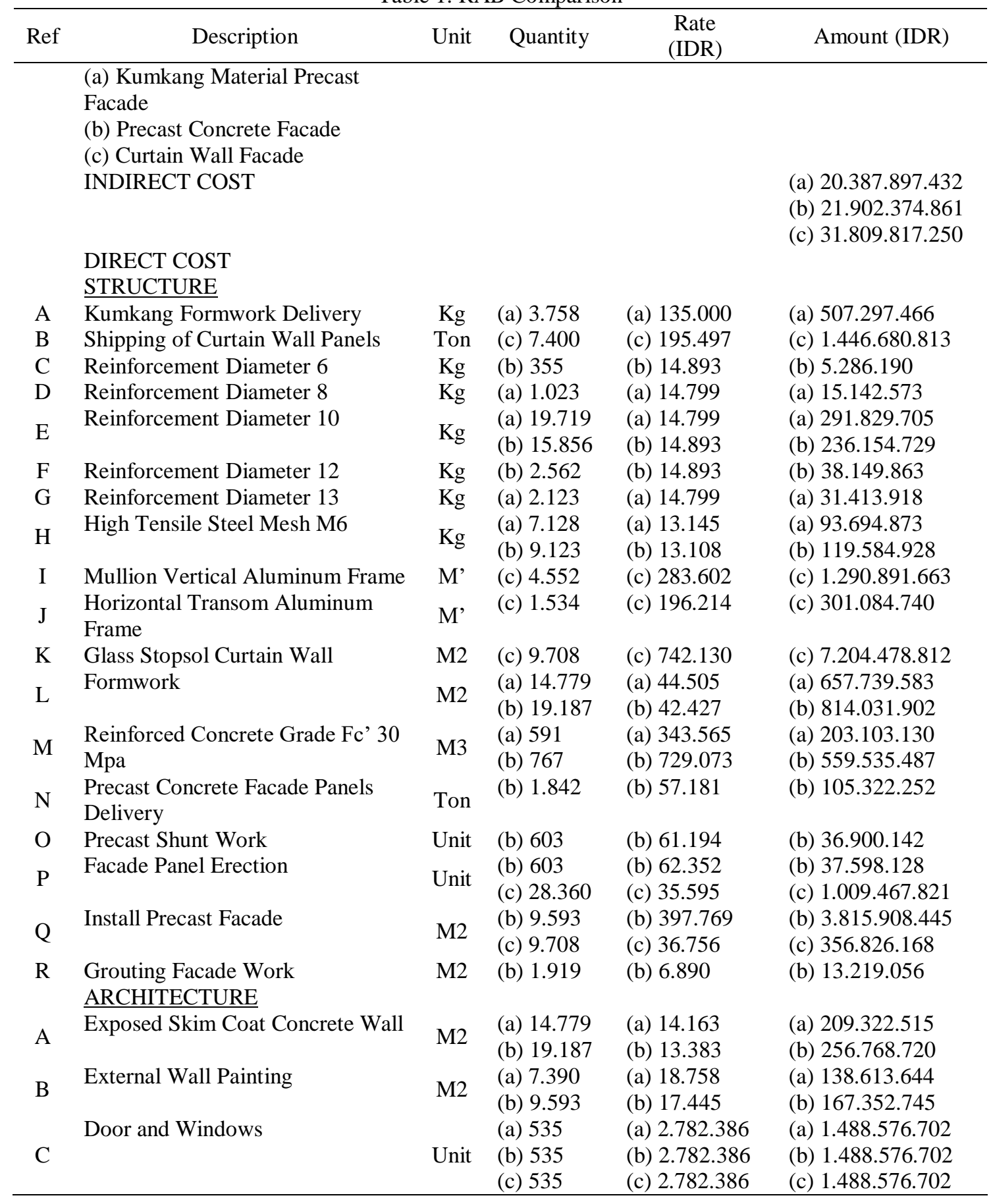

Table 1 shows indirect costs derived from staff costs and preparation costs by adjusting each method of facade work. As for the direct costs, which are divided into two categories of structural and architectural work, derived from all stages of the process to work on each facade method, the researcher calculates from unfinished materials to finished installing at the project site.

(2) The time analysis used worker productivity time in the AHSP coefficient to obtain the total time for each job and described in a bar chart. A bar chart is a set of activities place in a vertical column, while time is placed in a horizontal row. The start and end times of each activity and their duration are indicated by placing a horizontal block on the right side of each activity (Manto, 2016), as shown in the table below: 


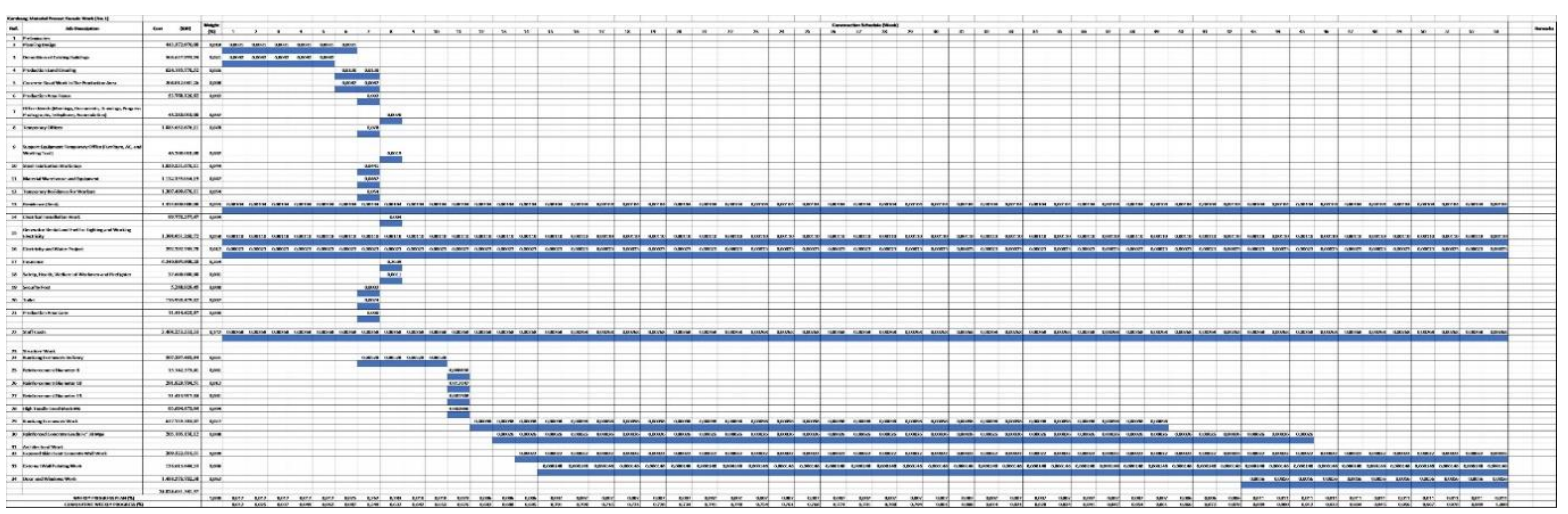

Figure 4. Bar Chart Facade Kumkang Material Precast

Figure 4 is a reduced kumkang precast facade bar chart, containing the entire work time.

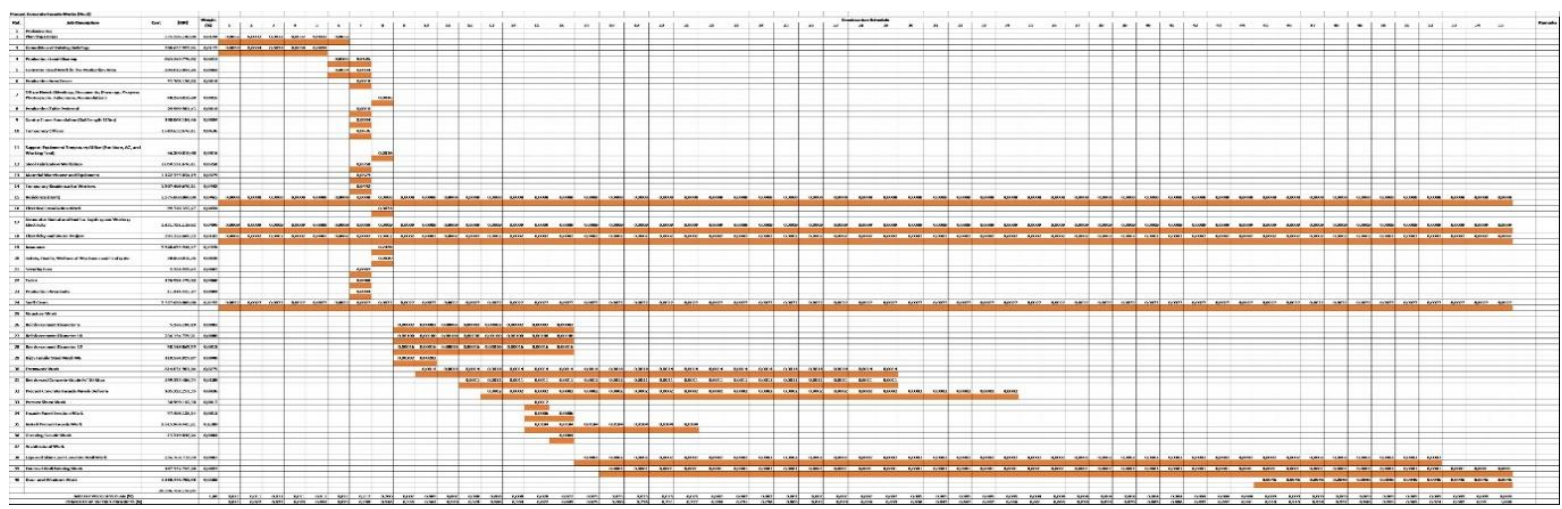

Figure 5. Bar Chart Facade Precast Concrete

Figure 5 is a reduced precast concrete facade bar chart, containing the overall working time

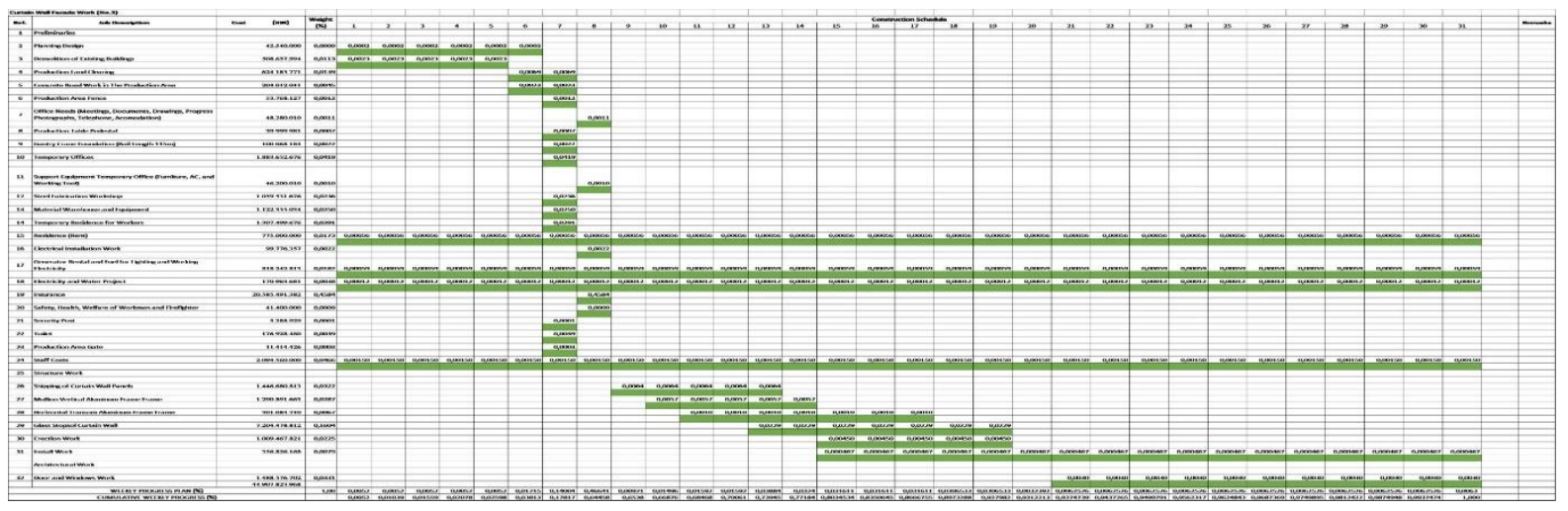

Figure 6. Curtain Wall Facade Bar Chart

Figure 6 is a reduced curtain wall facade bar chart, containing the overall work time.

Bar charts can use for making project scheduling. Figures 4, 5, and 6 describe the total scheduling it's explained assumption the researcher does overlapping work. The preliminaries work is carried by building temporary buildings at the project site simultaneously. Structural and architectural work does with the assuming of researchers that every structural work per floor is finish after the architectural will immediately follow, and so on until all work is complete.

This work is licensed under a Creative Commons Attribution-ShareAlike 4.0 International License. 
VOLUME 21 | NUMBER 02 | JANUARY 2022 https://ejournal.worldconference.id/index.php/neutron

E-ISSN: 2685-3272 | P-ISSN 1412-0860

Table 2. Facade Comparission

\begin{tabular}{|c|c|c|c|c|}
\hline Ref & Description & $\begin{array}{c}\text { Kumkang } \\
\text { Material Precast } \\
\text { Facade } \\
\text { (IDR) }\end{array}$ & $\begin{array}{c}\text { Precast } \\
\text { Concrete Facade } \\
\text { (IDR) }\end{array}$ & $\begin{array}{l}\text { Curtain Wall } \\
\text { Facade } \\
\text { (IDR) }\end{array}$ \\
\hline I & $\begin{array}{l}\text { EXTERIOR WORK } \\
\text { Indirect Cost }\end{array}$ & 20.387 .897 .432 & 21.902 .374 .861 & 31.809 .817 .250 \\
\hline II & Structure Works & & & \\
\hline A & Kumkang Formwork Delivery & 507.297 .466 & & \\
\hline $\mathrm{B}$ & Shipping of Curtain Wall Panels & & & 1.446 .680 .813 \\
\hline $\mathrm{C}$ & Reinforcement Diameter 6 Work & & 5.286 .190 & \\
\hline $\mathrm{D}$ & Reinforcement Diameter 8 Work & 15.142 .573 & & \\
\hline $\mathrm{E}$ & Reinforcement Diameter 10 Work & 291.829 .705 & 236.154 .729 & \\
\hline $\mathrm{F}$ & Reinforcement Diameter 12 Work & & 38.149 .863 & \\
\hline G & Reinforcement Diameter 13 Work & 31.413 .918 & & \\
\hline $\mathrm{H}$ & High Tensile Steel Mesh M6 Work & 93.694 .873 & 119.584 .928 & \\
\hline $\mathrm{I}$ & Mullion Vertical Aluminum Frame Work & & & 1.290 .891 .663 \\
\hline $\mathrm{J}$ & $\begin{array}{l}\text { Horizontal Transom Aluminum Frame } \\
\text { Work }\end{array}$ & & & 301.084 .740 \\
\hline $\mathrm{K}$ & Glass Stopsol Curtain Wall Work & & & 7.204.478.812 \\
\hline $\mathrm{L}$ & Formwork Work & 657.739 .583 & 814.031 .902 & \\
\hline M & $\begin{array}{l}\text { Reinforced Concrete Grade Fc' } 30 \mathrm{Mpa} \\
\text { (thick } 8 \mathrm{~mm} \text { ) }\end{array}$ & 203.103 .130 & 559.535 .487 & \\
\hline $\mathrm{N}$ & Precast Concrete Facade Panels Delivery & & 105.322 .252 & \\
\hline $\mathrm{O}$ & Precast Shunt Work & & 36.900 .142 & \\
\hline $\mathrm{P}$ & Facade Panel Erection & & 37.598 .128 & 1.009.467.821 \\
\hline Q & Install Precast Facade & & 3.815 .908 .445 & 356.826 .168 \\
\hline $\mathrm{R}$ & Grouting Facade Work & & 13.219 .056 & \\
\hline III & Architectural Works & & & \\
\hline A & Exposed Skim Coat Concrete Wall Work & 209.322 .515 & 256.768 .720 & \\
\hline $\mathrm{B}$ & External Wall Painting Work & 138.613 .644 & 167.352 .745 & \\
\hline $\mathrm{C}$ & Door and Windows Work & 1.488 .576 .702 & 1.488 .576 .702 & 1.488 .576 .702 \\
\hline 1 & $\begin{array}{l}\text { Additional Explanation : } \\
\text { Amount Per Square Meter }\end{array}$ & & & \\
\hline $\mathrm{a}$ & Structure & 551.014 & 1.384 .887 & 1.489 .794 \\
\hline $\mathrm{b}$ & Architectural & 2.815 .308 & 2.813 .214 & 2.782 .386 \\
\hline 2 & $\begin{array}{l}\text { Working Time (Architecture overlap of } \\
\text { finished structure) }\end{array}$ & Total 53 Weeks & Total 55 Weeks & Total 31 Weeks \\
\hline a & Structure & 39 Weeks & 26 Weeks & 23 Weeks \\
\hline $\mathrm{b}$ & Architectural & 40 Weeks & 39 Weeks & 11 Weeks \\
\hline 3 & $\begin{array}{l}\text { Number of Labor (Structure }+ \\
\text { Architecture) Per Square Meter }\end{array}$ & 23 Labor & 36 Labor & 26 Labor \\
\hline \multirow[t]{3}{*}{4} & Specification & $\begin{array}{l}\text { - Brand } \\
\text { (Kumkang } \\
\text { Kind) }\end{array}$ & - Brand (BEP) & $\begin{array}{l}\text { - Brand } \\
\text { (Asahimass) }\end{array}$ \\
\hline & & $\begin{array}{l}\text { - Cast-in-situ } \\
\text { concrete }\end{array}$ & $\begin{array}{l}\text { - Precast } \\
\text { Concrete } \\
\text { (Factory) }\end{array}$ & $\begin{array}{l}\text { - Special Attention } \\
\text { to The Connection }\end{array}$ \\
\hline & & $\begin{array}{l}\text { - Concrete Fc' } \\
30(\mathrm{t}=80 \mathrm{~mm})\end{array}$ & $\begin{array}{l}\text { - Concrete Fc' } \\
30(\mathrm{t}=80 \mathrm{~mm})\end{array}$ & $\begin{array}{l}\text { - Glass Stopsol } \\
\text { Dark Blue }(\mathrm{t}=80 \\
\mathrm{mm})\end{array}$ \\
\hline 5 & Advantages and Disadvantages & & & \\
\hline
\end{tabular}

This work is licensed under a Creative Commons Attribution-ShareAlike 4.0 International License. 
VOLUME 21 | NUMBER 02 | JANUARY 2022 https://ejournal.worldconference.id/index.php/neutron

E-ISSN: 2685-3272 | P-ISSN 1412-0860

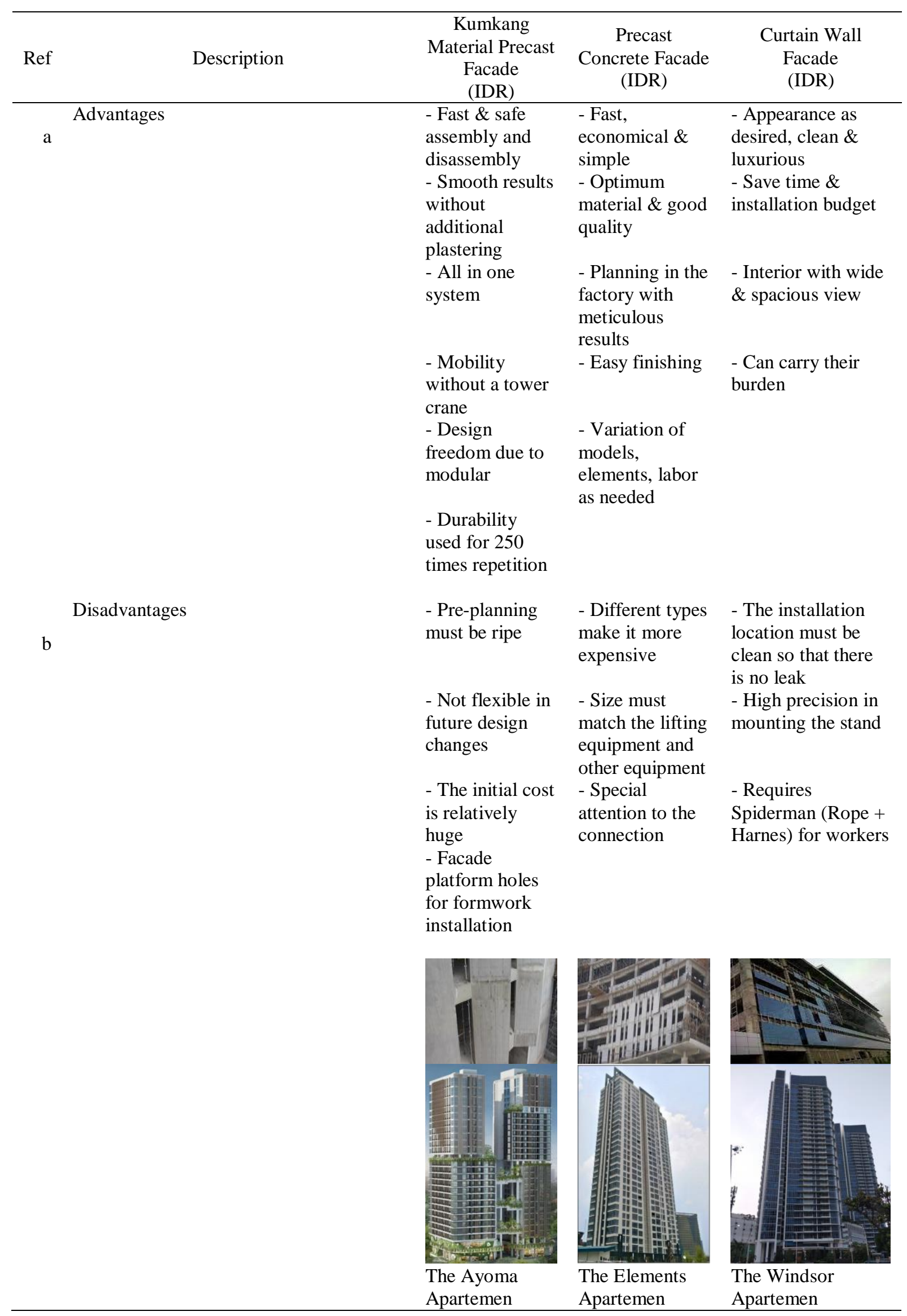

This work is licensed under a Creative Commons Attribution-ShareAlike 4.0 International License. 


\subsection{Discussion}

(1) In the RAB calculation, the indirect cost of the kumkang precast facade comes from staff costs for a total of 53 weeks of work, a total of $17 \%$ of the indirect costs of 3.4 billion, the rest is used for preparation costs, while the cost of the structure comes from the delivery of aluminum formwork from South Korea. Cast structure work on-site and architectural work carried out at the project site.

For indirect costs of precast concrete facades, the staff is calculated for a total working time of 55 weeks by $16 \%$ or 3.5 billion with the remaining preparation costs. The structure costs come from the manufacture of precast concrete facade panels at the factory site to delivery to the project site and the architectural cost required to complete the work at the project site.

And for curtain wall facades, indirect costs come from staff costs for 31 weeks of $7 \%$ or 2.1 billion and preparation work costs, besides structure work costs starting from the manufacturing process at the factory to installing aluminum and glass frames to finishing at the project site.

(2) In calculating the work time, the researcher used the labor productivity time in the AHSP coefficient for the unit of work and determined it according to the total volume of work required. Design work takes six weeks for all facade methods, all preparation time tailored to each work method, precast concrete takes at most 67 weeks, curtain wall takes at least 43 weeks, and precast kumkang material is 65 weeks. The total time required to precast the kumkang material is 159 weeks, precast concrete takes 182 weeks, and curtain wall takes at least 57 weeks. The researcher assumes that were preliminaries, structural and architectural works finished parallel, with the method of finished work per floor, the same as preliminaries work items can be done simultaneously.

To answer the background of the research problem on external aesthetics, the researchers measured using the Birkhoff formula, namely Aesthetic Measure. The validation results for construction project experts and university lecturers were four people, more than two people stated that the kumkang material precast facade expresses a very in order structure with the least amount of detail or complexity, precast concrete facade expresses a fairly aesthetic building with an average level of attractiveness, and the curtain wall facade expresses a building with poor aesthetics and with a high level of attractiveness.

\section{Conclussion}

Based on the research conducted, the researchers can conclude the following results as follow:

(1) The comparison cost of the facade work among the three methods are; kumkang material of precast is $24 \%$ cheaper than the facade of the precast concrete, then kumkang material of precast is $87 \%$ cheaper than the facade of the curtain wall method. And precast concrete facade is $52 \%$ cheaper than the facade of the curtain wall method. (2) The comparison work of the time of the facade work among three methods are; curtain wall method is 22 weeks faster than the kumkang material of precast facades. The curtain wall facade is 24 weeks faster than precast concrete facades, and the kumkang material of precast facades is two weeks earlier than the facade precast concrete method.

\section{Acknowledgements}

Thank were showed to the people who helped the researcher during the research process. Especially in terms of prayer, assistance, enthusiasm, attention, support, knowledge, and the opportunity to participate in the whole process of this research, namely to:

Dear writer's family. To the writer's closest friend and fellow regular civil engineering student 2 Mercu Buana University. Mrs. Irriene Indah Susanti, S.T, M.T as the Advisor for the Final Project. And the Mahata Margonda Apartment Project team and all parties who cannot be mention one by one.

\section{References}

AYOMA Apartment, T. P. T. (2018). Alform Effect (p. 126).

Hidayat, F., \& Irvan, G. (2018). Analisis Perbandingan Biaya, Waktu, Material, Dan Tata Laksana Pekerjaan Dinding Menggunakan Bata Ringan, Sandwich Panel, Dan Beton Precast Pada Proyek Pembangunan Rumah Sakit "STC" Di Kota Jakarta. Jurnal Teknik Sipil, 7(2), 40-51.

Manto, J. (2016). Mengidentifikasi Durasi Dan Tenaga Kerja Berdasarkan Analisa Harga Satuan Pekerjaan (AHSP) Pada Perencanaan Pekerjaan Perumahan Villa Idaman Boalemo. 4(1), 38-52.

Soenarto, A. U., Suprapti, A., \& Murtini, T. W. (2017). Preferensi Masyarakat Dalam Memilih Perumahan Berdasarkan Fasade Studi Kasus : Perumahan di Kecamatan Baki, Sukoharjo. Jurnal Arsitektur ARCADE, $1(2), 77-83$. 


\section{Biography / Biographies}

Irriene Indah Susanti S.T, M.T was born on January 15, 1983. She is active in construction management projects civil in Indonesia and also a lecturer in Construction Management at the Faculty of Civil Engineering, Mercu Buana University, Jakarta. Completed her Master's Degree in Civil Engineering with a concentration in Infrastructure Management from Bandung Institute Technology with the title of her thesis, "Application of Failure Mode and Impact Analysis (FMEA) on Airport Infrastructure.

Maria Siwi Tiarasari is a researcher for this subject, was graduated as a bachelor's degree student majoring in civil engineering at Mercu Buana University, Jakarta, Indonesia. Previously she was a diploma graduate majoring in civil engineering from the Jakarta State Polytechnic, Depok, Indonesia, with a final project topic was construction risk management. After graduating with a diploma in 3, she worked as an assistant quantity surveyor at PT Rider Levett Bucknall for approximately one year. Then she decided to stop and continue her studies as a student to get a bachelor's degree. While studying, she made a home renovation project with the output project is drawings, costs, and material needs. Where this project is a collaboration with her father as part of the construction drawings, and she is the one who calculates the costs like the previous work. Therefore, researchers are interested in understanding the cost of project construction more deeply and take this research for her final project as a requirement for undergraduate graduation. 